\title{
Forum
}

\section{Opuntia Forage Production Systems: Status and Prospects for Rangeland Application}

\author{
J. C. Guevara, ${ }^{1}$ P. Suassuna, ${ }^{2}$ and P. Felker ${ }^{3}$
}

Authors are ${ }^{1}$ Research Scientist, Argentinean Institute for Arid Land Research (IADIZA-CONICET) and Adjunct Professor, Department of Economics, Legal and Social Sciences, Agronomy Faculty, National University of Cuyo, Mendoza, PO Box 507, 5500, Mendoza, Argentina; ${ }^{2}$ Agricultural Engineer and Semiarid Tropical Consultant, Paulo Suassuna Consultoria Ltda., PO Box 166, Recife, PE, Brazil; and ${ }^{3}$ Research Scientist, D’Arrigo Bros, PO Box 850, Salinas, CA 93902, USA.

\begin{abstract}
This paper reports recent findings in Opuntia genetics, nutrient fertilization, and cultivation with promise to overcome limitations for Opuntia-based forage production systems. The essentially spineless, fast-growing Opuntia ficus-indica (L.) Mill. has been planted on millions of hectares for forage in tropical areas of Brazil and North Africa. The spiny, cold-hardy Opuntia species have been used for forage in Mexico and the southwestern United States, after the cladodes have been chopped or singed to remove the spines. Due to the recent increases in fuel prices, burning of the spines is more costly. Where only spiny varieties exist, some range animals forage on them without manipulation. As a result, spines frequently penetrate and form lesions on mouth and esophageal tissues, leading to serious health issues. Slow growth and low protein (ca. 5\%) of the native Opuntia spiny species on nonfertilized rangeland is an impediment to greater use of Opuntia for forage. The only spineless species adaptable to US Department of Agriculture cold hardiness zones $<8$ (i.e., Opuntia ellisiana Griffiths) is relatively slow growing. Full sibling crosses indicate spine heritability is probably single-gene controlled. Interspecific hybrids between the frost-sensitive, fast-growing, and spineless O. ficus-indica with cold-hardy, spiny, slower-growing O. lindheimerii Engelm. have produced spineless progeny, with greater cold hardiness than O. ficus-indica, and greater productivity than cold-hardy, spineless $O$. ellisiana. Nitrogen limitations on water-use efficiency of Opuntia have been overcome for the 120 million ha of semiarid northeastern Brazil with added nitrogen and phosphorus fertilization. With control of competing vegetation and fertilization, this system has $40 \mathrm{t}$ dry matter $\cdot \mathrm{ha}^{-1}$ of $9.2 \%$ crude protein forage with $600 \mathrm{~mm}$ rainfall in $16 \mathrm{mo}$. Opuntia ficus-indica plantations were profitable even though a duplication of fertilizer current prices was considered.
\end{abstract}

\section{Resumen}

Este trabajo reporta los hallazgos recientes en genética, fertilización, y cultivo de Opuntia que aseguran superar las limitaciones para los sistemas de producción de forraje que se basan en esta especie. La especie de crecimiento rápido O. ficus-indica (L.) Mill. que es una especie sin espinas que se ha plantado en millones de hectáreas para forraje en áreas tropicales de Brasil y norte de África. Las especies de Opuntia con espinas, más tolerantes al frío, se han utilizado para forraje en México y el sudoeste de Estados Unidos, después que se han picado o levemente quemado las plantas para remover las espinas. Debido al alza reciente de los precios del combustible, la quema de las espinas ha pasado a ser mucho más costosa. Donde sólo existen variedades espinosas, algunos animales las ingieren sin ningún manejo. Como resultado de ello, las espinas penetran y forman lesiones en la boca y en los tejidos del esófago, que conducen a serios problemas de salud. El crecimiento lento y el contenido bajo en proteína (alrededor del $5 \%$ ) de las especies espinosas de Opuntia nativas en pastizales nativos no fertilizados es un obstáculo para un uso mayor de Opuntia para forraje. La única especie sin espinas adaptable a las zonas de tolerancia al frío del Departamento de Agricultura de los Estados Unidos de Norteamérica $<8$ (O. ellisiana Griffiths) es de crecimiento relativamente lento. Cruzas totales entre hermanos indican que la heredabilidad de las espinas está probablemente controlada por un gen simple. Híbridos interespecíficos entre O. ficus-indica, de crecimiento rápido, sensible al frío y sin espinas con O. lindheimerii Engelm., resistente al frío, con espinas y de crecimiento más lento, han identificado progenie sin espinas, con mayor resistencia al frío que O. ficusindica y mayor productividad que O. ellisiana, especie sin espinas y tolerante al frío. Se han superado las limitaciones de $\mathrm{N}$ sobre la eficiencia del uso del agua por parte de Opuntia para las 120 millones de hectáreas de la zona semiárida del noreste de Brasil mediante la fertilización con nitrógeno y fósforo. Este sistema ha producido 40 toneladas de materia seca por hectárea con 9,2\% de proteína bruta con $600 \mathrm{~mm}$ de lluvia anual mediante el control de la vegetación competitiva y la fertilización después de 16 meses. Las plantaciones de O. ficus-indica resultaron rentables aún si se considera una duplicación del precio actual de los fertilizantes.

Key Words: cold hardiness, cultural practices, economic feasibility, fertilization, progeny

\section{INTRODUCTION}

Research was funded in part by the National University of Cuyo, Program P-05.

Correspondence: J. C. Guevara, IADIZA, PO Box 507, 5500, Mendoza, Argentina. Email: jguevara@mendoza-conicet.gov.ar

Manuscript received 7 November 2008; manuscript accepted 14 June 2009.
As forage for range livestock, Opuntias have both advantages and disadvantages. Spines and smaller glochids of the areoles are a distinctive feature of nearly all cacti that cause mechanical injury to the skin, face, and digestive tract, and are a strong 
deterrent to most herbivores. Feeding these species requires mechanical or flame treatments prior to feeding. Occasionally, sheep, goats, and cattle eat spiny cactus that have not had the spines removed, resulting in infected lesions in their digestive tract and poor health or death of these livestock (Migaki et al. 1969; Merrill et al. 1980).

In the continental United States, another negative attribute of Opuntia is that native spiny Opuntias are slow growing whereas the spineless, fast-growing species such as O. ficusindica (L.) Mill. are not cold-hardy and are poorly adapted to most US rangelands. The low protein concentration of unfertilized cactus $(5-6 \%$ crude protein [CP]; Everitt and González 1981; Meyer and Brown 1985) is another limitation when feeding grazing animals.

On the positive side, these cacti have greater water-use efficiency due to the crassulacean acid metabolism (CAM) photosynthetic pathway that is several times more efficient in converting water and $\mathrm{CO}_{2}$ to dry matter plants than either $\mathrm{C}_{4}$ or $\mathrm{C}_{3}$ plants (Nobel 1991, 1994; Han and Felker 1997). Cacti can produce more dry matter per milimeter of rainfall than any other type of plant. When high population densities are planted, $O$. ficus-indica is very productive. Simulations (García de Cortázar and Nobel 1990) under natural conditions led to a maximum predicted productivity of about $20 \mathrm{t}$ dry matter $\cdot \mathrm{ha}^{-1} \cdot \mathrm{yr}^{-1}$ worldwide. Measurements with no water limitations gave $40 \mathrm{t}$ dry matter $\cdot \mathrm{ha}^{-1} \cdot \mathrm{yr}^{-1}$ in Chile (García de Cortázar and Nobel 1991). A very high density planting $\left(24\right.$ plants $\left.\cdot \mathrm{m}^{-2}\right)$ with unlimited water and ample nutrients led to $50 \mathrm{t} \cdot \mathrm{ha}^{-1} \cdot \mathrm{yr}^{-1}$ in Chile (García de Cortázar and Nobel 1992) and O. ficus-indica fertilized and watered daily had a productivity of $47 \mathrm{t} \cdot \mathrm{ha}^{-1} \cdot \mathrm{yr}^{-1}$ in Mexico (Nobel et al. 1992). With high nitrogen (N) and phosphorus (P) applications in Texas to O. lindheimerii Engelm., González (1989) obtained $62 \mathrm{t}$ dry matter $\cdot \mathrm{ha}^{-1} \cdot \mathrm{yr}^{-1}$.

Worldwide, the greatest use of cactus for forage occurs in Mexico, South Africa, Tunisia, and Brazil (Mondragón-Jacobo and Pérez-González 2001; Felker et al. 2006). Flores and Aranda (1997) reported that 18 Opuntia species were used as forage on more than 3 million ha of rangeland in northern Mexico with 150000 ha of cactus being planted by ranchers and small producers using government support. López et al. (1996) reported that 25 species and 12 varieties of Opuntia are being used for forage in the Mexican state of Coahuila. Flores and Aranda (1997) reported that more than 650000 cattle died during the 1993 to 1996 drought in northern Mexico yet ranchers with nopales (Opuntia) appeared to have fewer livestock losses than ranchers without nopales. Furthermore, reproduction rates and production levels were greater for animals supplemented with nopales.

In Brazil (Domingues 1963; Cordeiro Dos Santos and Gonzaga de Albuquerque 2001) and Tunisia (Monjauze and Le Houérou 1965; Nefzaoui and Ben Salem 2001), there are plantations with several hundred thousand hectares of spineless Opuntia that are used for livestock feed. Extensive spiny Opuntia stands in Tigray, Ethiopia, also have been used for livestock food after the spines have been chopped (Brutsch 1997). In South Africa considerable scientific study has been devoted to utilization of cactus for forage (De Kock 2001). All of the cacti used commercially for livestock in the United States is of the wild spiny type, i.e., O. lindheimerii in Texas (Felker 1995) and to a lesser extent O. polyacantha Haw. in Colorado (Shoop et al. 1977).
CAM species show an average increase in biomass productivity of $35 \%$ in response to a doubled atmospheric $\mathrm{CO}_{2}$ concentration (Drennan and Nobel 2000), predicted to occur before the end of the twenty-first century (Nobel 1996). With increasing temperature and drought duration, the percentage enhancement of daily net $\mathrm{CO}_{2}$ uptake caused by elevated $\mathrm{CO}_{2}$ concentration increases. Thus net $\mathrm{CO}_{2}$ uptake, productivity, and the potential area for cultivation of CAM species will be enhanced by the increasing atmospheric $\mathrm{CO}_{2}$ concentration and the increasing temperatures associated with global climate change (Drennan and Nobel 2000). Similarly, Nobel (1996) indicated a further expanding of CAM plants in the regions where they profitably can be cultivated.

Nutrient content of Opuntia spp. depends on the genetic characteristics of the species or clones, the cladode's age, the cladode sampling location, the cladode harvesting season, and the growing conditions, such as soil fertility and climate (Monjauze and Le Houérou 1965; Boza et al. 1995; Nefzaoui and Ben Salem 2001; Gugliuzza et al. 2002; Guevara et al. 2006). Opuntia ficus-indica was high in calcium (Ca), normal in magnesium $(\mathrm{Mg})$, and low in sodium $(\mathrm{Na})$, potassium $(\mathrm{K})$, and $\mathrm{P}$ contents in relation to ruminant requirements from a diet, and similar to common temperate or tropical grasses and legumes (Tegegne 2001). Iron and aluminium are found in traces (López-García et al. 2001). In Opuntia spp., Ca is the main mineral constituent of the plants. It is found in a free form or as calcium oxalate. This salt can reach from $8 \%$ to $50 \%$ of dry matter (DM) and to $85 \%$ in the ashes of old plants (TovarPuente et al. 2007). Cactus cladodes have high oxalate content; total oxalate is about $13 \%$ of the DM, of which $40 \%$ is in a soluble form. These oxalates are probably bound to $\mathrm{Ca}$, making this mineral less available to animals. Cactus feed, i.e., cladodes aged 1-3 yr is rich in provitamin A and vitamin C (Le Houérou 1996). Vitamin A is likely the vitamin of most practical importance in cattle feed. Vitamin A does not occur as such in plant material; however, its precursors, carotenes or carotenoids, are present in plants in various forms (National Research Council [NRC] 2000). The content of carotenoids is $29 \mu \mathrm{g}$ $100 \cdot \mathrm{g}^{-1}$ and the content of ascorbic acid is $13 \mathrm{mg} 100 \cdot \mathrm{g}^{-1}$ (Felker 2001). The nutrient content of seven Opuntia forage clones and three age classes (about $1 \mathrm{yr}, 2 \mathrm{yr}$, and 3 yr old) was determined in the Mendoza plain, Argentina (Guevara et al. 2004). The nutrient content for all clones and age classes pooled was the following ( $\% \mathrm{DM})$ : organic matter $(\mathrm{OM})$, $81.6 \%$ to $86.8 \%$; in vitro organic matter digestibility, $69.5 \%$ to $82.1 \%$; CP, $3.2 \%$ to $5.0 \%$; neutral detergent fiber, $22.7 \%$ to $27.1 \%$; acid detergent fiber, $12.0 \%$ to $16.0 \%$; DM, $7.3 \%$ to $11.5 \%$. A significant $(P<0.05)$ or nearly significant $(P=0.08)$ linear negative relationship between each nutritional parameter and age classes was found for all clones, except for OM that showed a significant linear relationship with only two clones.

Below we discuss some factors limiting the use of Opuntia for forage and provide methods to overcome these limitations.

\section{Fertilization to Increase Crude Protein Contents}

With $\mathrm{N}$ fertilization, typically low protein concentrations of Opuntia can be increased to attain 10\% CP $(\mathrm{N} \times 6.25)$, a level meeting the needs of a lactating cow (González 1989). Nobel (1983) measured $\mathrm{N}$ concentrations of O. ficus-indica cladodes 
in a California plantation near Los Angeles. In his study, cladodes averaged $15.3 \%$ CP. Nitrogen fertilization in O. ficusindica fruit plantations near Salinas, California has resulted in cladode protein concentrations of $15 \%$ in 1-yr-old cladodes (P. Felker, unpublished observations, August 2008).

The protein concentration in Opuntia is quite sensitive to soil nutrient status. González (1989) conducted a fertilizer trial using $\mathrm{N}$ and $\mathrm{P}$ fertilizer on yield and tissue concentration of the Texas spiny wild $\mathrm{O}$. lindheimerii and found that the CP increased from $4.5 \%$ for the control (no $\mathrm{N}$ and $\mathrm{P}$ additions) to $10.5 \%$ protein for additions of $224 \mathrm{~kg} \mathrm{~N} \cdot \mathrm{ha}^{-1}$ and $112 \mathrm{~kg}$ $\mathrm{P} \cdot \mathrm{ha}^{-1}$. There are reports of $\mathrm{N}$-fixing symbiotic relationships of Opuntia with Azospirillum (Rao and Venkateswarlu 1982; Mascarúa-Esparza et al. 1988; Caballero-Mellado 1990) that need to be tested in the field for enhanced productivity and protein content.

\section{Fertilization and Cultural Practices to Increase Productivity to $\geq 300 \mathrm{t} \cdot \mathrm{ha}^{-1} \cdot \mathrm{yr}^{-1}$ Fresh Weight}

Three studies in Texas looked at methods to increase productivity of the native $O$. lindheimerii. Hanselka and Falconer (1994) noted that after root plowing, prickly pear populations exploded and dominated the community with approximately $16.8 \mathrm{t} \cdot \mathrm{ha}^{-1}$ wet weight. In a trial adding $\mathrm{N}$ and $\mathrm{P}$ amendments in a factorial design, González (1989) measured a mean annual dry matter biomass productivity of a wild $O$. lindheimerii variety in a 430-mm annual precipitation zone. In this study he measured total biomass of $52 \mathrm{t} \cdot \mathrm{ha}^{-1}$ after $4 \mathrm{yr}$ with the highest $\mathrm{N}$ and $\mathrm{P}$ application rates. In a water-balance study that estimated surface, runoff, soil evaporation (microlysimeters), and drainage (neutron probes), Han and Felker (1997) reported that the $17.7 \mathrm{t} \cdot \mathrm{ha}^{-1}$ dry matter productivity of $\mathrm{O}$. ellisiana Griffiths was measured during the fourth year's growth after photosynthetic area (analogous to Leaf Area Index) reached 2.02. This level of productivity was achieved with $662 \mathrm{~mm}$ rainfall and $285 \mathrm{~mm}$ water being transpired, for a transpiration water-use efficiency of $162 \mathrm{~kg}$ water $\cdot \mathrm{kg}^{-1} \mathrm{DM}$.

Despite the fact that $O$. ellisiana grows slower than most commercially raised Opuntias this is among the highest transpiration water-use efficiencies measured in replicated studies (Han and Felker 1997). This is an important attribute when considering most climate change scenarios for most arid and semiarid environments.

Snyman (2005) found that $95 \%$ of O. ficus-indica roots were in the upper $15 \mathrm{~cm}$ of soil. Thus, when fertilization is applied to Opuntias, it is important to apply frequent, low application rates to avoid leaching the nutrients below the root zone. Possibly due to this very shallow root system, Felker and Russell (1988) measured a $300 \%$ increase in Opuntia biomass when herbicides were used to control vegetation competing with Opuntia.

Unfortunately the advantage of potentially large water-use efficiency of CAM metabolism in Opuntias cannot be realized with very low annual $\mathrm{N}$ inputs (ca. $1-2 \mathrm{~kg} \mathrm{~N} \cdot \mathrm{ha}^{-1} \cdot \mathrm{yr}^{-1}$ ) typical of semiarid lands (Geesing et al. 2000). As a result, the productivity of Opuntias on nonfertilized rangelands can be very low and the $\mathrm{CP}$ concentration of the edible portion of 1and 2-yr-old cladodes is often as low as $4-5 \%$ and thus well below the minimal requirements for a beef cow $(6-13 \%$ $\mathrm{CP} \cdot \mathrm{DM}^{-1}$; NRC 2000). When the $\mathrm{N}$ inputs/effluxes from a rangeland ecosystem are in a hypothetical steady state equilibrium, there is no net change in soil and vegetation pool sizes in $\mathrm{N}$. In this case no more $\mathrm{N}$ can be taken from the system than enters the system. If only $2 \mathrm{~kg} \mathrm{~N} \cdot \mathrm{ha}^{-1} \cdot \mathrm{yr}^{-1}$ enter the system, no more than that can be taken off in a sustainable manner. Assuming a low cladodal concentration of $0.8 \mathrm{~kg}$ $\mathrm{N} \cdot 100 \mathrm{~kg} \mathrm{DM}{ }^{-1}(5 \% \mathrm{CP})$, then only $250 \mathrm{~kg} \mathrm{DM} \cdot \mathrm{ha}^{-1} \cdot \mathrm{yr}^{-1}$ can be sustainably harvested without external $\mathrm{N}$ inputs.

Nobel (1983) has demonstrated that increased chlorenchyma $\mathrm{N}$ increased nocturnal acid accumulation. This increased nocturnal acid concentrations, increasing the total amount of phosphoenol pyruvate carboxylase (PEP) enzyme that is the first step in CAM metabolism. If the total PEP activity increased, this would create a greater flux of $\mathrm{CO}_{2}$ into the cladodes. Because water-use efficiency is the ratio of water transpired per carbon gain, increased $\mathrm{N}$ could increase the water-use efficiency of cacti. Felker and Bunch (2009) have assumed constant water-use efficiency for CAM, $\mathrm{C}_{4}$, and $\mathrm{C}_{3}$ plants in a graphic representation of productivity vs. annual rainfall containing fixed ceilings on productivity that were placed according to annual $\mathrm{N}$ inputs. This clearly demonstrated that high water-use efficiencies of cacti cannot be utilized unless considerable $\mathrm{N}$ inputs are applied.

Suassuna (2008) used fertilization to overcome the N and P limitations to Opuntia biomass productivity on a farm at $630 \mathrm{~m}$ elevation (lat $08^{\circ} 02^{\prime} 23.7^{\prime \prime} \mathrm{S}$, long $37^{\circ} 03^{\prime} 23.9^{\prime \prime} \mathrm{W}$ ) with about $600 \mathrm{~mm}$ rainfall per year in northeastern Brazil. Production practices included banded surface applications of $600 \mathrm{~kg}$ urea $\cdot \mathrm{ha}^{-1}, 1200 \mathrm{~kg}$ of phosphate $\cdot \mathrm{ha}^{-1}$, and $15 \mathrm{t}$ of dry manure $\cdot \mathrm{ha}^{-1}$ for a plant population of 60000 plants $\cdot \mathrm{ha}^{-1}$. Competing vegetation was overcome with use of pre-emergent (ametryne, diuron, tebuthiuron, simazine, and atrazine) and postemergent (glyphosate) herbicides. With these inputs, $40 \mathrm{t} \cdot \mathrm{ha}^{-1} \mathrm{DM}$ containing $9.2 \% \mathrm{CP}$ was obtained in $16 \mathrm{mo}$. An example of the biomass after 16 mo in rainfed northeastern Brazil is shown in Figure 1. For $480 \mathrm{~d}(16 \mathrm{mo})$ at a daily fresh weight requirement of $40 \mathrm{~kg}$ for cattle, and from $3 \mathrm{~kg}$ to $9 \mathrm{~kg}$ for sheep and goats (López-García et al. 2001), 1 ha would support 25 cattle, and from 113 to 340 goats or sheep.

The productivity of $40 \mathrm{tDM} \cdot \mathrm{ha}^{-1}$ is in agreement with that of Nobel et al. (1992), who reported an average productivity of $48 \mathrm{t} \cdot \mathrm{ha}^{-1} \cdot \mathrm{yr}^{-1}\left(564 \mathrm{t} \cdot \mathrm{ha}^{-1}\right.$ fresh weight at $\left.8.5 \% \mathrm{DM}\right)$ for O. amyclaea Ten. and O. ficus-indica that were fertilized and watered daily in Saltillo, Coahuila, Mexico and of $40 \mathrm{t} \cdot \mathrm{ha}^{-1} \cdot \mathrm{yr}^{-1}\left(470 \mathrm{t}\right.$ fresh weight $\left.\cdot \mathrm{ha}^{-1}\right)$ for intensively managed O. ficus-indica in Chile (García de Cortázar and Nobel 1991). At $194 \mathrm{t} \cdot \mathrm{ha}^{-1}$ O. ellisiana had less fresh weight growth during the fourth year of growth than the O. ficusindica (Han and Felker 1997). However, as opposed to the continuously irrigated cacti in the Chilean and Mexican studies, for the O. ellisiana, $240 \mathrm{~mm}$ of the $662 \mathrm{~mm}$ annual rainfall occurred in four heavy thunderstorms that ran off or quickly percolated below the 15 -cm-deep root zone.

With regard to the $\mathrm{N}$ fertilization sustainability, we consider that because the naturally occurring $\mathrm{N}$ input without legumes is only about $2 \mathrm{~kg} \cdot \mathrm{ha}^{-1} \cdot \mathrm{yr}^{-1}$, then without $\mathrm{N}$ inputs, grazing is not sustainable if the cow consumes more than $4 \mathrm{~kg}$ $\mathrm{N} \cdot \mathrm{ha}^{-1} \cdot \mathrm{yr}^{-1}$ (due to the $50 \%$ loss in volatilization of $\mathrm{N}$ in urine and feces). 


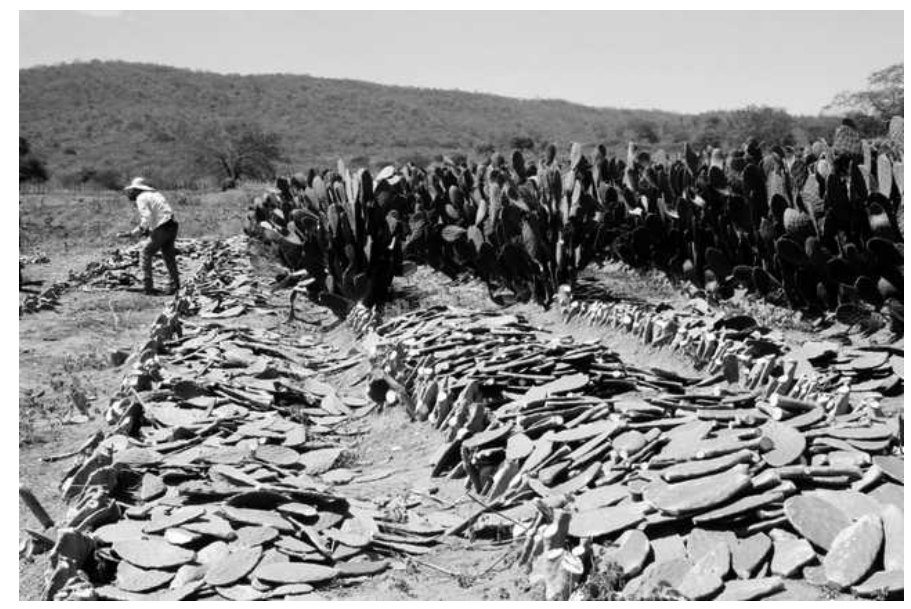

Figure 1. Harvest of $40 \mathrm{t} \cdot \mathrm{ha}^{-1}$ dry weight from 16-mo-old Opuntia ficus-indica under intensive management in a 600-mm annual precipitation zone at $630-\mathrm{m}$ elevation (lat $08^{\circ} 02^{\prime} 23.7^{\prime \prime} \mathrm{S}$, long $37^{\circ} 03^{\prime} 23.9^{\prime \prime} \mathrm{W}$ ) in northeastern Brazil.

When fed as an exclusive diet, cladodes cause diarrhea after about $6 \mathrm{wk}$ for cattle, and 8 wk for sheep, limiting Opuntia use as a single feed to short periods (Le Houérou 1996). According to Le Houérou (1996), diarrhea easily can be prevented and/or cured by adding to the diet approximately $1 \%$ dry roughage (straw, hay, browse, grazing) on a body weight basis, in other words by offering a ration with a minimum overall DM content of $25-30 \%$. The high amount of oxalates might explain the laxative effect of cladodes when fed to animals (Nefzaoui and Ben Salem 2001).

\section{Genetic Improvement to Increase Cold Hardiness of Spineless Selections}

Opuntia, which is insect-pollinated and has self-fertile flowers, can be diploid, triploid, tetraploid, and octaploid $(n=11$; Weedin and Powell 1978; Powell and Weedin 2001). Wang et al. (1996) reported emasculation and bagging techniques for Opuntia and examined the sterility barriers between commercial O. ficus-indica fruit types, O. lindheimerii, O. ellisiana, and a few apparent hybrid species. O. ficus-indica was found to produce fertile offspring with the spiny Texas native $O$. lindheimerii but not with $O$. ellisiana, or a putative hybrid forage clone No. 1233. In Mendoza, Argentina, O. ellisiana suffered no frost damage when temperatures dropped to $-15^{\circ} \mathrm{C}$ during two brief occasions $(2-3 \mathrm{hr})$ in the winter of 2000 (Guevara et al. 2003a). However, as mentioned earlier, $O$. ellisiana is slow-growing. It would be desirable to have a spineless Opuntia with the same cold hardiness of O. ellisiana but with much faster growth rate.

Opuntias possess two different types of "spines" arising from the areoles that are objectionable to livestock and humans. One is the spines that can vary from about one to several centimeters in length. The other is the nearly microscopic $(100 \mu$ in diameter by about $1500 \mu$ long) hair-like barbed spines known as glochids. These characters appear to be under separate genetic control, because some $O$. lindheimerii have no spines on portions of their cladodes but have very abundant glochids. In contrast some $O$. ficus-indica fruit varieties with long spines have very reduced glochids. The O. ficus-indica variety Opuntia ficus-indica L. f. inermis (Web.) Le Houér. (Guevara et al. 2006) is nearly devoid of glochids and spines, whereas O. ellisiana (1364) has many fewer glochids than the typical "spineless" O. ficus-indica. Although spine length was similar for O. lindheimerii clones made by Texas rancher W. A. Maltsberger (Maltsberger 1996), the percentage of areoles with spines varied from 3.3\% to $47.7 \%$ (Chávez-Ramírez et al. 1997).

The genetic control of spine production appears to be relatively simple. In hybridization studies among the octaploid "commercial fruit type" Opuntias, when the female parent was spineless and the male parent spiny, $57 \%$ of the progeny $(n=84)$ were spineless. When the female parent was spiny and the male parent was spineless, $63 \%$ of the progeny $(n=84)$ were spineless, and when both parents were spineless, $92 \%$ of the progeny $(n=155)$ were spineless (P. Felker, unpublished observations, July 2003). Collectively, these data suggest that spinelessness is simply inherited. The recovery of spiny genotypes from spineless parents suggests that this (albeit small) sampling of parental genotypes each contained alleles for both the spineless and the spiny condition.

One hundred and fifty seedlings from the O. ficus-indica $\times O$. lindheimerii cross were evaluated in the field in Argentina where the majority were found to be apomicts (unfertilized seed derived from maternal tissue) and thus clonally identical to the female $O$. ficus-indica parent. However, some of the segregates had many of the characteristics of the cold-hardy, spiny male parent (small fruit and bluish cladodes) but without spines. We believe these will possess increased cold tolerance over the spineless O. ficusindica and possibly the other spineless Opuntia types. An example of a 3-yr-old spineless progeny between O. ficus-indica and O. lindheimerii that possessed cladode shape and color of the male O. lindheimerii phenotype is presented in Figure 2. Ten such progeny currently are being evaluated in various cold hardiness zones of the Argentine central arid zone at lat $33^{\circ} \mathrm{S}$ by Juan Carlos Guevara of the Argentinean Institute for Arid Land Research (unpublished data).

Spiny and spineless seedlings emerged from the feces of wildlife that had eaten the fruit of spineless types in South Africa and later spread over vast areas. Thus sterility in forage types would be a significant advantage when introducing them to new areas. All of the bagged, nonmanipulated flowers of Opuntia accession No. 1233 developed into fruits, but these fruits abscised (Wang et al. 1996), indicating that this clone might be sterile.

Because O. lindheimerii is sufficiently cold hardy and adapted to conditions throughout most of Texas, and $O$. ficus-indica lacks cold hardiness, but is spineless and fastgrowing, a combination of the two provides a genetic route to produce cold-hardy, spineless forage Opuntias for Texas. Other crosses to examine, if sexual compatibility exists, is a cross between spineless types and the spiny $O$. polyacantha, once used for forage in Colorado (Shoop et al. 1977). Opuntia polyacantha is adapted to lat $56^{\circ} \mathrm{N}$ in Alberta, Canada (Stelfox and Friend 1977) and O. australis F. A. C. Weber is adapted to lat $50^{\circ} \mathrm{S}$ in Argentina.

The new hybrids are intermediate in chromosome number between the parents (O. linheimerii is hexaploid, O. ficusindica is octaploid, and the hybrids are heptaploid) and trials to cross these back to O. ficus-indica were not successful due to chromosome issues. This means that they probably will not 


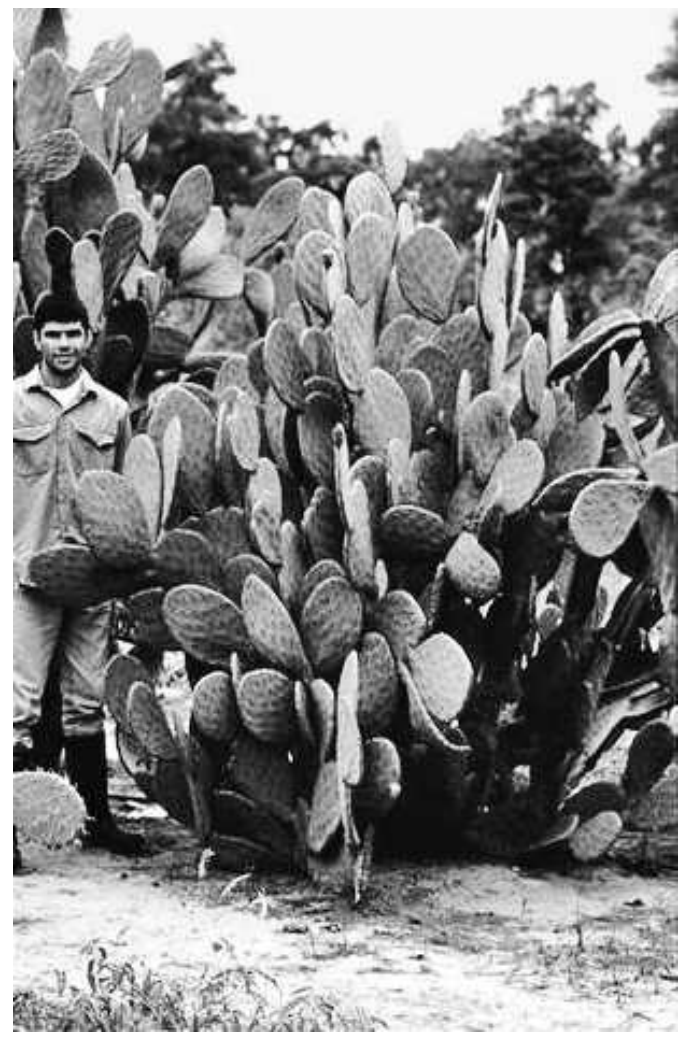

Figure 2. Three-year-old thornless segregant of a cross between spineless Opuntia ficus-indica 1281 (female parent) $\times$ Opuntia lindheimerii 1250 (male parent). Opuntia lindheimerii is a cold-hardy, native species from Texas. The progeny have many characteristics of the cold-hardy male parent. The progeny were grown in Santiago del Estero, Argentina, in a $650-\mathrm{mm}$ annual precipitation zone dominated by summer rainfall. These plants were fertilized once a year with $150 \mathrm{~g} \cdot$ plant $^{-1} 15-$ 15-15 fertilizer that was banded around the base of the plants, and competing plants removed with diuron and glyphosate.

cross with the wild Opuntias. Varieties without spines or glochids are extremely susceptible to herbivory from all sizes of mammals (rabbits, deer, etc.) and substantial fencing is needed to protect them.

\section{Opuntia Pests and Diseases}

Granata and Sidoni (2002) reported that the numerous pests and diseases present in Opuntia ficus-indica in the producer area worldwide are caused by bacteria, yeasts, fungi, phytoplasmas, and viruses, and abiotic factors such as atmospheric conditions. The diseases often result in severe damage, especially in cladodes, roots, and fruits. Because some of the diseases can jeopardize the entire cultivation, stricter control should be exercised on propagative material and on importation from other countries. Prevention often is the best way to control the diseases and keep them from spreading into areas that are not affected. The study by Granata and Sidoni (2002) reports on the major cactus diseases present in the growing areas, the characteristics of the causal agent, the symptomology, and the control measures.

The main pests that can cause economic damage to Opuntia in Brazil are the cochineal insect (Diaspis sp. and Dactylopius opuntiae), caterpillars, grasshoppers, and ants. The main disease that can cause economic damage to Opuntias is rotting caused by fungus. Applying insecticides $\left(1 \mathrm{~L} \cdot \mathrm{ha}^{-1}\right)$ of one of the following products: Confidor, Provado, Carbaril, Endosulfan, or Carbofuran, and fungicides $\left(1 \mathrm{~kg} \cdot \mathrm{ha}^{-1}\right)$ such as Metiltiofan or Cercotim, produced significant results in the control of grasshoppers, ants, and fungi (Suassuna 2008). The possibility of using biological and other alternative methods to control pest populations of Diaspis echinocacti, which is an important pest of Opuntia spp. in northeast Brazil, was studied by de Souza Born et al. (2009).

Cactoblastis cactorum is a common pest in Opuntia ficusindica in the northeastern region of Argentina. To determine the efficacy of different insecticides for its control, Carbaril (CA; $0.16 \mathrm{~L} \cdot 100 \mathrm{~L}^{-1}$ ), Deltrametrin (DEL; $0.01 \mathrm{~L} \cdot 100 \mathrm{~L}^{-1}$ ), Endo-

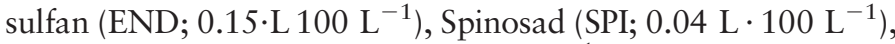
and Triflumuron (TRI; $0.03 \mathrm{~L} \cdot 100 \mathrm{~L}^{-1}$ ) were tested in the laboratory by Lobos et al. (2002). Mortality ranged from $20 \%$ to $100 \%$. CA, DEL, and SPI performed well as contact insecticides and their efficacy improved when used with adjuvants.

In arid zones (200-300 mm mean annual precipitation) pests and diseases were not recorded (J. C. Guevara, personal observation, October 2007). The previous information implies that pests and diseases would not influence a livestock producer's decision to include Opuntia in their forage mix.

\section{Economic Evaluation of Opuntia Forage Management Systems}

The economic feasibility of 50-ha, 100-ha, and 200-ha O. ficusindica plantations was evaluated for semiarid northeastern Brazil (600 $\mathrm{mm}$ annual precipitation) and the Argentina central arid zone $(300 \mathrm{~mm}$ annual precipitation) under a cut-and-carry management system. Cacti plantations in Brazil included annual fertilization as was previously mentioned. Those in Argentina were not fertilized. The basic data (establishment and operating costs in January 2008 currency) were derived from our previous studies (Guevara et al. 1999; Suassuna 2008). Monetary value of cactus forage was estimated using as the shadow price the cost of energy and protein derived from those of concentrate forages (De Montgolfier-Kouèvi and Le Houérou 1980) for the period 19972006 (in January 2008 currency). The capital opportunity cost was assumed to be $12 \%$. The period of analysis for computing the internal rate of return (IRR) was $20 \mathrm{yr}$. If the IRR is higher than the capital opportunity cost, cacti plantations are profitable. The results are presented in Table 1.

The IRR in Brazil was about six times the capital opportunity cost, i.e., the intensive cactus plantation has a high profitability. The threshold of $12 \%$ IRR was reached in Argentina at $15 \mathrm{t}$ $\mathrm{DM} \cdot \mathrm{ha}^{-1} \cdot \mathrm{yr}^{-1}$ for a 100 -ha plantation, with the IRR threshold being reached for all cactus production levels harvested. Most nitrogen fertilizers are derived from increasingly scarce fossil fuel. If we consider that the $\mathrm{N}$ fertilizer cost could duplicate the current one, the IRR for 50 ha in Brazil, for example, would drop from $73.5 \%$ to $47.2 \%$. This implies that the probable increase in $\mathrm{N}$ fertilizer cost would not affect the economics of forage Opuntia.

\section{MANAGEMENT IMPLICATIONS}

Combining these new findings and management options creates the potential to produce $300 \mathrm{t} \cdot \mathrm{ha}^{-1} \mathrm{yr}^{-1}$ of fresh forage in marginal arid and semiarid environments that provide more than 
Table 1. Internal rates of return of cactus plantations in Brazil and Argentina according to the planting area and the forage production (dry matter [DM]).

\begin{tabular}{cccc}
\hline Zone & $\begin{array}{c}\text { Plantation area } \\
\text { (ha) }\end{array}$ & $\begin{array}{c}\text { Cactus forage production } \\
\left(\mathrm{t} \mathrm{DM} \cdot \mathrm{ha}^{-1} \cdot \mathrm{yr}^{-1}\right)\end{array}$ & $\begin{array}{c}\text { Internal rate of } \\
\text { return }(\%)\end{array}$ \\
\hline Brazil & 50 & 31.2 & 73.5 \\
& 100 & & 73.9 \\
& 200 & & 74.1 \\
Argentina & 50 & 5.6 & 3.2 \\
& & 10.0 & 4.7 \\
& \multirow{2}{*}{100} & 15.0 & 6.2 \\
& & 5.6 & 8.0 \\
& & 10.0 & 10.6 \\
& 200 & 15.0 & 12.5 \\
& & 5.6 & 12.1 \\
& & 10.0 & 15.2 \\
& & 15.0 & 17.5 \\
\hline
\end{tabular}

9\% crude protein (DM basis) and $60-70 \%$ digestible dry matter. Furthermore, it appears some planned accessions can withstand freezing temperatures to US Department of Agriculture cold hardiness zone 7.

We foresee three major types of utilization for these technologies: 1) as a year-long source of forage, 2) forage reserves during drought ("drought insurance"), and 3) to supplement seasonal forage shortages. In Argentina, need is greatest during late fall and winter when goat parturition occurs and forage reserves are scarce (Guevara et al. 2003b).

In summary, new techniques for making interspecific crosses between wild, well-adapted, spiny but slow-growing Opuntia species, with fast-growing spineless, domesticated species creates new opportunities for much more useful, productive, and high water-use efficiency Opuntia forage varieties. Combinations of these new varieties with intensive management systems, including high $\mathrm{N}$ inputs, show great promise for overcoming the past issues with spiny, low-productive Opuntias to dramatically improve forage production from rangeland. Cactus plantations are a profitable activity for rangelands of semiarid and arid zones.

\section{ACKNOWLEDGMENTS}

Authors thank Ed L. Fredrickson and one anonymous reviewer for providing valuable comments on a previous version of the manuscript.

\section{LITERATURE CITED}

Boza, J., J. Fonolla, and J. H. Silva. 1995. Utilización de la chumbera (Opuntia ficus-indica) en alimentación animal. Avances en Alimentación y Mejora Animal 35:3-6. (In Spanish).

Brutsch, M. 0. 1997. The beles or cactus pear (Opuntia ficus-indica) in Tigray, Ethiopia. Journal of the Professional Association for Cactus Development 2:130-141.

Caballero-Mellado, J. 1990. Potential use of Azospirillum in association with prickly pear cactus. Proceedings of First Annual Texas Prickly Pear Council. Kingsville, TX, USA: Texas A\&M University Kingsville. p. 14-21.

Chávez-Ramírez, F., X. Want, K. Jones, D. Hewett, and P. Felker. 1997. Ecological characterization of Opuntia clones in south Texas: implications for wildlife herbivory and frugivory. Journal of the Professional Association for Cactus Development 2:9-19.

Cordeiro Dos Santos, D., and S. Gonzaga de Albuquerque. 2001. Fodder use in the semi- arid northeast of Brazil. In: C. Mondragón-Jacobo and S. Pérez-González [EDs.]. Cactus (Opuntia spp) as forage. Rome, Italy: Food and Agriculture Organization. p. 37-50.

DE Kock, G. C. 2001. The use of Opuntia as a fodder source in arid areas of southern Africa. In: C. Mondragón-Jacobo and S. Pérez-González [EDS.]. Cactus (Opuntia spp) as forage. Rome, Italy: Food and Agriculture Organization. p. 101-105.

De Montgolfier-Kouèvi, C., and H. N. Le Houérou. 1980. Study on the economic viability of browse plantations in Africa. In: H. N. Le Houérou [ED.]. Browse in Africa. The current state of knowledge. Addis Ababa, Ethiopia: International Livestock Centre for Africa. p. 449-464.

de Souza Born, F., M. J. Cerqueira de Araújo, H. Monaísy Alencar Lima, V. de Melo Rodrigues, S. M. Forti Broglio-Micheletti, R. C. Prédes Trindade, E. E. Pintos de Lemos, and D. M. Passos da Silca. 2009. Control of Diaspis echinocacti (Bouché, 1833) (Hemiptera: Diaspididae) in prickly-pear. Acta Horticulturae 811:223-226.

Domingues, 0. 1963. Origem e introducao da palma forrageira no nordeste. Recife, Brazil: Instituto Joaquim Nabuco de Pesquisas Socias. 74 p. (In Portuguese).

Drennan, P. D., and P. S. Nobel. 2000. Responses to CAM species to increasing atmospheric $\mathrm{CO}_{2}$ concentrations. Plant, Cell \& Environment 23:767-781.

EveritT, J. H., AND C. L. González. 1981. Seasonal nutrient content in foods of white tailed deer on the South Texas Plains. Journal of Range Management 34:506-510.

FeLKeR, P. 1995. Forage and fodder production and utilization. In: G. Barbera, P. Inglese, and E. Pimienta-Barrios [EDS.]. Agroecology, cultivation and uses of cactus pear. Rome, Italy: Food and Agriculture Organization. p. 144-154.

Felker, P. 2001. Utilization of Opuntia for forage in the United States of America. In: C. Mondragón-Jacobo and S. Pérez-González [Eds.]. Cactus (Opuntia spp.) as forage. Rome, Italy: Food and Agriculture Organization. p. 51-56.

Felker, P., And R. A. Bunch. 2009. Mineral nutrition of cactus for forage and fruits. Acta Horticulturae 811:389-394.

Felker, P., A. Paterson, and M. M. Jenderek. 2006. Forage potential of Opuntia clones maintained by the USDA, National Plant Germplasm System (NPGS) collection. Crop Science 46:2161-2168.

Felker, P., and C. E. Russell. 1988. Influence of herbicides and cultivation on the growth of Opuntia in plantations. Journal of Horticultural Science 63:149-155.

Flores, C., and G. Aranda. 1997. Opuntia based ruminant feeding systems in Mexico. Journal of the Professional Association for Cactus Development 2:3-9.

García de Cortázar, V., and P. S. Nobel. 1990. Worldwide environmental productivity indices and yield predictions for a CAM plant, Opuntia ficus-indica, including effects of doubled $\mathrm{CO}_{2}$ levels. Agricultural and Forest Meteorology 49:261-279.

García de Cortázar, V., and P. S. Nobel. 1991. Prediction and measurement of high annual productivity for Opuntia ficus-indica. Agricultural and Forest Meteorology 56:261-272.

García de Cortázar, V., and P. S. Nobel. 1992. Biomass and fruit production for the prickly pear cactus Opuntia ficus-indica. Journal of the American Society for Horticultural Science 117:558-562.

Geesing, D., P. Felker, and R. L. Bingham. 2000. Influence of mesquite (Prosopis glandulosa) on soil nitrogen and carbon development: implications for global C sequestration. Journal of Arid Environments 46:157-180.

González, C. L. 1989. Potential of fertilization to improve nutritive value of prickly pear cactus (Opuntia lindheimerii Engelm.). Journal of Arid Environments 16:87-94.

Granata, G., and A. Sidoni. 2002. Survey of diseases discovered on Opuntia ficusindica in producer countries. Acta Horticulturae 581:231-237.

Guevara, J. C., O. R. Estevez, and C. R. Stası. 1999. Economic feasibility of cactus plantations for forage and fodder production in the Mendoza plain (Argentina). Journal of Arid Environments 43:241-249.

Guevara, J. C., J. H. Silva-Colomer, and 0. R. Estevez. 2004. Nutrient content of Opuntia forage clones in the Mendoza plain, Argentina. Journal of the Professional Association for Cactus Development 6:62-77.

Guevara, J. C., J. H. Silva-Colomer, O. R. Estevez, and J. A. Paez. 2003b. Simulation of the economic feasibility of fodder shrub plantations as a supplement for 
goat production in the north-eastern plain of Mendoza, Argentina. Journal of Arid Environments 53:85-98.

Guevara, J. C., J. H. Silva-Colomer, M. C. Juárez, and 0. R. Estevez. 2003a. Opuntia ellisiana: cold hardiness, above-ground biomass production and nutritional quality in the Mendoza plain, Argentina. Journal of the Professional Association for Cactus Development 5:55-64.

Guevara, J. C., S. 0. Trione, 0. R. Estevez, and M. A. Cony. 2006. A sampling procedure to determine the nitrogen content in Opuntia ficus-indica cladodes. Journal of the Professional Association for Cactus Development 6:63-72.

Gugliuzza, G., T. La Mantia, and P. Inglese. 2002. Fruit load and cladode nutrient concentrations in cactus pear. Acta Horticulturae 581:221-224.

Han, H., AND P. FeLKer. 1997. Field validation of water use efficiency of a CAM plant Opuntia ellisiana in south Texas. Journal of Arid Environments 36:133-148.

Hanselka, C. W., and L. L. Falconer. 1994. Pricklypear management in South Texas. Rangelands 16:102-106.

Le Houérou, H. N. 1996. The role of cacti (Opuntia spp.) in erosion control, land reclamation, rehabilitation and agricultural development in the Mediterranean Basin. Journal of Arid Environments 33:135-159.

Lobos, E., J. OCHOA, ANd C. Soulier. 2002. Cactoblastis cactorum Berg (Lepidoptera, Pyralidae) preliminary studies for chemical control. Acta Horticulturae 581:247-251.

López, J. J., A. Rodríguez-G, L. Perez-R, and J. M. Fuentes-R. 1996. A survey of forage uses of cactus in northern Mexico. Journal of the Professional Association for Cactus Development 1:10-19.

López-García, J. J., J. M. Fuentes-Rodríguez, and R. A. Rodríguez. 2001. Production and use of Opuntia as forage in northern Mexico. In: C. Mondragón-Jacobo and S. Pérez-González [eds.]. Cactus (Opuntia spp) as forage. Rome, Italy: Food and Agriculture Organization. p. 29-36.

Maltsberger, B. 1996. Cactus as a resource for cattle and wildlife. Journal of the Professional Association for Cactus Development 1:3-10.

Mascarúa-Esparza, M. A., R. Villa-González, and J. Caballero-Mellado. 1988. Acetylene reduction and indoleacetic acid production by Azospirillum isolates from Cactaceous plants. Plant and Soil 106:91-95.

Merrill, L. B., C. A. Taylor, R. Dusek, and C. W. Livingston. 1980. Sheep losses from range with heavy prickly pear infestation. In: D. N. Ueckert and J. E. Huston [EDS.]. Rangeland resources research. San Angelo, TX, USA: Texas Agricultural Experiment Station Consolidated Progress Report 3665. 91 p.

Meyer, M. M., And R. D. Brown. 1985. Seasonal trends in the chemical composition of ten range plants in south Texas. Journal of Range Management 38:154-157.

Migaki, G., L. E. Hinson, G. D. Imes, and F. M. Garner. 1969. Cactus spines in the tongues of slaughtered cattle. Journal of the American Veterinary Medical Association 155:1489-1492.

Mondragón-Jacobo, C., and S. Pérez-González. 2001. Germplasm resources and breeding Opuntia for fodder production. In: C. Mondragón-Jacobo and S. Pérez-González [eds.]. Cactus (Opuntia spp) as forage. Rome, Italy: Food and Agriculture Organization. p. 21-28.

Monjauze, A., and H. N. Le Houérou. 1965. Le role des Opuntia dans l'economie agricole Nord Africaine. Bulletin de l'Ecole Nationale Superiéure d'Agriculture de Tunis 8-9:85-164.
Nefzadui, A., and H. Ben Salem. 2001. Opuntia spp. A strategic fodder and efficient tool to combat desertification in the WANA region. In: C. Mondragón-Jacobo and S. Pérez-González [eds.]. Cactus (Opuntia spp) as forage. Rome, Italy: Food and Agriculture Organization. p. 73-89.

NoBEL, P. S. 1983. Nutrient levels in cacti-relation to nocturnal acid accumulation and growth. American Journal of Botany 70:1244-1253.

NoBeL, P. S. 1991. Tansley Review no. 32. Achievable productivities of CAM plants: basis for high values compared with $\mathrm{C}_{3}$ and $\mathrm{C}_{4}$ plants. New Phytologist 119:183-205.

NobeL, P. S. 1994. Remarkable agaves and cacti. New York, NY, USA: Oxford University Press. 180 p.

Nobel, P. S. 1996. Responses to some North American CAM plants to freezing temperatures and doubled $\mathrm{CO}_{2}$ concentrations: implications of global climate change for extending cultivation. Journal of Arid Environments 34:187196.

Nobel, P. S., E. Garcia-Moya, and E. Quero. 1992. High annual productivity of certain agaves and cacti under cultivation. Plant, Cell and Environment 15:329-335

NRC [National Research Council]. 2000. Nutrient requirements of beef cattle, 7th revised ed. Washington, DC, USA: National Research Council. 248 p.

Powell, A. M., and J. F. Weedin. 2001. Chromosome numbers in Chihuahuan Desert Cactaceae. III. Trans Pecos Texas. American Journal of Botany 88:481-485.

Rao, A. V., and B. Venkateswarlu. 1982. Associative symbiosis of Azospirillum lipoferum with dicotyledonous succulent plants of the Indian desert. Canadian Journal of Microbiology 28:778-782.

Shoop, M. C., E. J. Alford, and H. F. Mayland. 1977. Plains prickly pear is a good forage for cattle. Journal of Range Management 30:12-17.

Snyman, H. A. 2005. A case study on in situ rooting profiles and water-use efficiency of cactus pears, Opuntia ficus-indica and 0 . robusta. Journal of the Professional Association for Cactus Development 7:1-21.

Stelfox, J. G., and H. G. Friend. 1977. Prairie fires and pronghorn use of cactus. The Canadian Field Naturalist 91:282-285.

SuAssunA, P. 2008. A review of applied Opuntia forage production technologies and costs for north eastern Brazil. Journal of the Professional Association for Cactus Development 10:171-197.

Tegegne, F. 2001. Nutritional value of Opuntia ficus-indica as a ruminant feed in Ethiopia. In: C. Mondragón-Jacobo and S. Pérez-González [EDS.]. Cactus (Opuntia spp.) as forage. Rome, Italy: Food and Agriculture Organization. p. 91-99.

Tovar-Puente, A., M. Pando-Moreno, H. González-Rodríguez, L. Scott-Morales, and S. de J. Méndez Gallegos. 2007. Densidad de cristales de oxalato de calcio en quince cultivares de nopal. Journal of the Professional Association for Cactus Development 9:91-98.

Wang, X., P. Felker, A. Paterson, Y. Mizrahi, A. Nerd, and C. Mondragón-Jacobo. 1996. Cross-hybridization and seed germination in Opuntia species. Journal of the Professional Association for Cactus Development 1:49-60.

WeEdin, J. F., And A. M. Powell. 1978. Chromosome numbers in Chihuahuan desert Cactaceae. Trans-Pecos Texas. American Journal of Botany 65:531-537. 